\title{
A survey of micorrhizal infection in an amazonian rain forest
}

\author{
T. V. St. John $\left({ }^{*}\right)$
}

\begin{abstract}
A survey of mycorrhizal infection and depth of rootlets was carried out on a hectare of primary rain forest in which all individuals over $15 \mathrm{~cm}$ in diameter had been identified and labeled. Non-mycorrhiza!, lightly infected, moderately infected, and heavily infected species made up $16.7,23.2,14.8$, and $16.7 \%$, respectively, of the total plot's ecological importance value. Of the plot's total importance value, $59.9 \%$ were found to have fine roots in the 0 - to $10-\mathrm{cm}$ depth range, $7 \%$ to be in the 10-to $30-\mathrm{cm}$ range, and $7.9 \%$ to have roots deeper than $30 \mathrm{~cm}$. A strong association was found between root depth and mycorrhizal condition, with surface roots much more likely to be infected than deep roots. Rootlet depth was shown to be a consistent trait within a species and most often within a genus. The deep-rooted, non-mycorrhizal condition was interpreted as an ecological "strategy" for avoiding competition with more efficient mycorrhizal species.
\end{abstract}

\section{INTRODUCTION}

In spite of the known importance of mycorrhizal fungi in mineral nutrition of plants (Gerdemann, 1975; Bowen, 1973) and much speculation about the importance of these fungi in tropical ecosystems (McLean, 1919; Richards, 1953, Went \& Stark, 1968), such basic ecological data as distribution and abundance of infection in tropical forests remain scarce. The nearest approach to this kind of information is in various surveys of tropical habitats: lists of species, including some natives (Janse, 1897); Johnson, 1949; Redhead, 1968); a short list of natives (Edmisten, 1970); or a determination based on unidentified root fragments (Stark, 1970). Only the last report allows the overall amundance of infection to be assessed, and its data apparently refer only to surface roots. A study of an area of primary tropical rain forest in which all individuals had been identified and labeled (Prance et al., 1976) offered an cpportunity to obtain such data in some detail. An index of importance value was calculated for each species as a means of identifying dominant or ecologically significant species in the forest. Species with high importance value were given priority in sampling. Each sampled species was assignea to one of four classes of infection by a semiquantitative evaluation of intensity of infection. Finally, the depth at which each root sample was recovered was recorded.

\section{METHODS AND MATERIALS}

\section{IMPORTANCE VALUE}

Phytosociological data from Prance et al. (1976) were used $t$ ogenerate an index of importance value for each species on the plot. We modified the importance value index of Curtis \& McIntosh (1950) to exclude a measure of frequency. Since only one quadrat was used and all species occurred on it, the frequency values are all equal and this measure contributes nothing to the importance value index. Our index was converted to an importance percentage value as done by Risser \& Rice (1971) Our index was $\left(\mathrm{N}_{i}+\mathrm{BA}_{i}\right) / 2$. where $\mathrm{N}_{i}$ is the fraction of the total number of individuals comprised by species $\mathrm{i}$, and $\mathrm{BA} \mathrm{i}$ is the fraction of the total basal area comprised by species i.) Species were selected in order of decreasing importance value, except that non-mycorrhizal taxa were more extensively sampled.

\section{COLLECTION OF ROOT SAMPLES}

The study site was a hectare of lowland evergreen rainforest on a very heavy oxisol near Manaus, Brazil. It is described in detail by Prance et al. (1976). In every case, a root specimen was collected by following a root

(") - Instituto Nacional de Pesquisas da Amazônia, Manaus. 
outward from the base of an identified plant until non-woody, ultimate-order rootlets of confirmed identity were encountered. Usually about $50 \mathrm{~cm}^{3}$ (loosley arranged) of these roots were returned to the laboratory for preparation. The depth in the soil from which eac sample was taken was recorded.

\section{PREPARATION AND EVALUATION OF ROOT SAMPLES}

Root specimens were cleared and strained by the method of Phillips \& Hayman (1970) and examined with a dissecting miccroscope. Subsamples thought likely to be infected were mounted in glycerin on slides and examined under a compound microscope. The usual basis for judging infection was the presence of characteristic internal hyphae. Vesicles were not common and arbuscules were almost never evident in field-collected riative plants. Occasional root specimens were so opaque that satisfactory clearing was not achieved witn these techniques; in such cases, judgement was based on external hyphae of the characteristic endogonaceous type.

Plants rated "non-mycorrhizal" were never found to support infection. Those rated lightly infected had occasional, isolated infection points. Those "moderately infected" had many parts infected, and those heavily infected had most of the roots infested with hyphae or other V-A mycorrhizal structures. Ectomycorrhizae were determined by the presence of a hyphal mantle on ultimate-order rootlets. Only three ectomycorrhizal species were found. Two of these were Neea spp. (Nytaginaceae), which Dr. Rolf Singer had already found to be ectomycorrhizal on other sites (personal communication). The third was Gnetum sp.; the ectomycorrhizal condition of this specimen was confirmed by Dr. Singer.

Non-mycorrhizal species, unless rare, were collected at least twice. The most common species were collected several times, usually from different trees, regardless of mycorrhizal condition.

Permanent mounts were made of at least one collection of each species.

\section{DATA MANIPULATION}

Calculation of importance value, sums of I.V., and counts of species in each category were carried out with the aid of the computer facility (CDC 6000) of Colorado State University, Fort Collins, Colorado U.S.A.

Extrapolation of results was done by assuming that mycorrhizal condition of insampled species is the same as the closest relative actually sampled.

\section{RESULTS}

Mycorrhizal infection was assessed in $71.4 \%$ (86 species) and fine-root depth in $74.8 \%$ (89 species) of the total importance value (greater than $15-\mathrm{cm}$ diameter) of the plot. The fraction of total importance value in each category of infection is shown in Table 1. The fraction in each of three classes of root depth is shown in Table 1. Values for each species are given in the Appendix.

TABLE 1 - Percent of total importance value in each category of infection and root depth

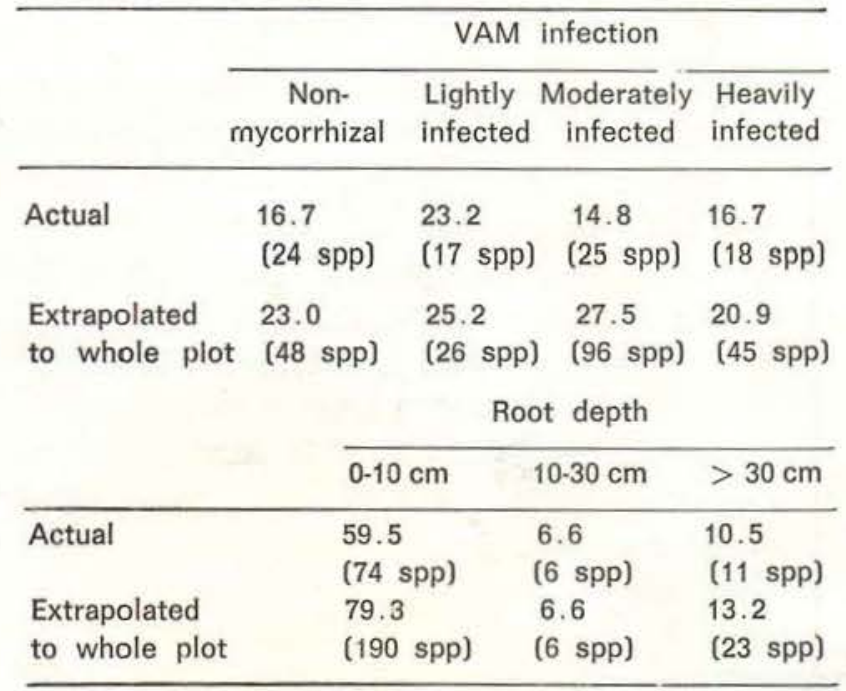

\section{Discussion}

Although the mycorrhizal categories to which different individuals of the same species were assigned varied somewhat, they never differed by more than one category. If addition. al examples were collected, the appropriate category for a given species could always be 
decided. At the generic level, mycorrhizal condition was constant in some genera and varied in others. Three representatives of each of the genera Protium and Brosimum were all heavily infected. Three species of Swartzia (including one from a different site) were all non-mycorrhizal. Of seven representatives of Eschweilera, all but one were lightly infected. Certain genera showed wider variation: Couepia had both a heavily and a lightly infected representative, and Pouteria had two non-mycorrhizal and a moderately infected species. Constancy within genus seems to be the usual condition, however. At the family level, some of the families are constant and others quite variable. All three legume families consistently have either moderate or heavy infection, ecept Swartzia of the Caesalpiniaceae. Lauraceae, Vochysiaceae, and Lecythidaceae also show little variability, while the important families Moraceae and Sapotaceae are notable for wide variation.

From these observations, mycorrhizal condition of about $97 \%$ of the plot's importance value can be estimated from congeners and family reprpesentatives actually examined. Ciearly, such extrapolation is more reliable for consistent generaand families; but since these are more frequent than inconsistent ones, the estimate should be reasonably accurate. The fraction of total importance value estimated to occur in each category of infection intensity is shown in Table 1. It differs somewhat from that actually sampled because non-mycorrhizal plants, many of high importance value, are over represented in the sample actually examined. The Lecythidaceae in particular was over reprepresented in the field work because it offered an opportunity to substantiate the somewhat surprising finding that many species were non-mycorrhizal or only lightly infected. In view of this over representation, the whole forest may well be characterized better by the extrapoiated data than by the actual sample.

The depth of fine roots was a very consistent characteristic of a species. Different individuals of the same species differed by more than a few $\mathrm{cm}$ in only one case. Thus, depth of ultimate-order iaterals is clearly a genetically controlled trait in this forest, not simply a response to local environmental variables, and may reasonably be consiaered an important component of a species ecological niche in this environment of intense competition for limited nutrients. At the generic revel, rooting depth was again remarkably unitorm, as exemplified by Protium, Eschweilera, Brosimum, and Pouteria. Some variability is found in Couepia, Salacia, and Saccoglottis. Again, some families are constant (legumes excep Swartzia, Lauraceae, Moraceae and Vochysiaceae) and others variable (Lecythidaceae, Meliaceae), but uniformity is more frequent and the entire forest may be characterized better by the extrapolated root-depth data (Table 1) than by the original sample.

The statistically significant association $(p<0.01)$ between root depth and infection level (Table 2) is a warning to those who would do a survey of mycorrhizal infection and

TABLE 2 - Number of species in mycorrhizal categories at three classes of root depth

\begin{tabular}{cccc}
\hline $\begin{array}{c}\text { Depth } \\
(\mathrm{cm})\end{array}$ & $\begin{array}{c}\text { Non- } \\
\text { mycorrhizal }\end{array}$ & $\begin{array}{c}\text { Liphtly } \\
\text { infected }\end{array}$ & $\begin{array}{c}\text { Moderately Heavily } \\
\text { infected }\end{array}$ \\
\hline
\end{tabular}

\begin{tabular}{rrrrr}
$0-10$ & 22 & 19 & 65 & 34 \\
$10-30$ & 0 & 3 & 6 & 0 \\
$>30$ & 14 & 0 & 0 & 0 \\
\hline
\end{tabular}

$X_{2}=60.6 ; P<0.01$.

could explain the differences between this and earlier tropical surveys: Because shalloworoted species are much more likely than deeprooted species to be infected and a single collection of deep-rooted species can take as long as a week, over emphasizing the easy species, an almost certain consequence of casual sampling, could prompt the conclusion that the amount of infection is unrealistically high. Table 2 also indicates that deep roots and the non-mycorrhizal condition are apparently associated components of an ecological strategy. Shallow-rooted, mycorrnizal species almost certainly obtain phosphorus (the nutrient most likely to limit growth in this soil) more efficiently than deep-rooted species Because they remain out of competition, deeprooted species use a different soil volume and 
are probably able either to obtain phosphorus without the aid of mycorrhizal fungi, as discussed by Baylis (1975) and for the Amazon region by St. John (1980), or to tolerate low internal concentrations of phosphorus, perhaps by mechanisms similar to those discussed by Beadle (1966), Benzing (1973), or Small (1972).

Although the association between root depth and mycorrhizal infection has been reported by others (Mejstrik \& Dominik, 1969; St. John \& Machado, 1978), this study shows that deep, non-mycorrhizal roots are a consistent feature of certain species in this environment.

A number of non-mycorrhizal species have shallow roots. The question of their competition with mycorrhizal species will be discussed in a forth-coming publication.

The division of the soil volume between species with different fine-root depths is clearly one niche dimension that, combined with mycorrhizal state and other parameters. may eventually enabie us to demonstrate resource partitioning among tropical trees. Connell (1978) suggested that rain forest species do not differ sufficiently to occupy different niches; these data indicate that they do, however, and show the direction in which we may fruitfully seek measurable components of niche.

\section{ACKNOWLEDGMENTS}

The field work of this study was funded by a grant to Dr. Paulo de Tarso Alvim from the Conselho Nacional de Pesquisas. Preparation of the manuscript was supported by Natıonal Science Foundation Grant DEB 78-11201.

\section{RESUMO}

Foram feitas observações da intensidade de infecção por micorriza em radículas de plantas, sendo que todas com mais de $15 \mathrm{~cm}$ de diâmetro foram identificadas e etiquetadas, plantas estas situadas em um hectare de floresta primária chuvosa. Não micorrítica, pouco infectada, moderadamente infectada, e espécies abundantemente infectadas receberam o seguinte valor de importância ecológica em área circunscrita: $16,7 \% ; 23,2 \% ; 14,8 \%$ e $16,7 \%$. Do valor de importância total $59,9 \%$. Foi encontrado para finas raízes $0-10 \mathrm{~cm}$ de profundidade, $7 \%$ para $10-30 \mathrm{~cm}$, e $7,9 \%$ para raízes profundas abaixo de $30 \mathrm{~cm}$.
Uma grande correlação foi encontrada entre profundidade no cilindro radicular e condição micorrítica, com a superficie da raiz provavelmente mais infectada que zonas mais internas. Radículas profundas foi uma característica consistente em espécies e muitas vezes em gêneros. Raízes profundas năo micorríticas foram interpretadas como uma estratégia ecológica para evitar competição com espécies micorríticas mais eficientes

\section{LITERATURE}

BAYLIS, G.T.S.

1975 - The magnoloid mycorrhiza and mycotrophy in root systems derived from it. IN: Sanders, F.E., Tinker, P.B. \& Mosse, B (eds.) Endomycorrhizas. Academic Press, London.

Beadle, N.C.W.

1966 - Soil phosphate and its role in molding segments of the Australian flora and vegetation, with special reference to xeromorphy and sclerophylly. Ecology, 47: 9921007.

BENZING, D.H.

1973 - The monocotyledons: Their evolution and comparative biology. I. Mineral nutrition and related phenomena in bromeliaceae and Orchidaceae. The Quarterly Review of Biology, 48: 277-290

BOWEN, G.D.

1973 - Mineral nutrition of Ectomycorrhiza. IN: Marks, G.C. \& Kozlowski, J.T.T., (eds.). "Ectomycorrhizae: Their Ecology and Physiology". New York, Academic Press. p. 151-205.

CONNELL, J.H.

1978 - Diversity in tropical rain forests and coral reefs. Science, 199: 1302-1310

CURTIS, J.T. \& MCINTOSH, R.P.

1950 - The interrelations of certain analytic synthetis phytosociological characters. Ecology, 31: $434-455$

EDMISTEN, J.

1970 - Survey of mycorrhiza and modules in the El Varde forest. IN: Odum, H.T. "A Tropical Rain forest". F-2: F15-126.

GERDEMANN, J.W

1975 - Vesicular-Arbuscular mycorrhizae. In: Tor. rey, J.G. \& Clarkson, D.T. (eds.). "Development and Function of Roots", London Academic Press. p. 575-591.

JANSE, J.M.

1897 - Les endophytes radicaux javanvaises. Ann. Jard. Bot., Buitenzorg, 14: 53-212.

JOHNSTON, A.

1949 - Vesicular-Arbuscular mycorrhiza in sea island cotton and other tropical plants Trop. Agric., Trin., 26: 118-121. 
MC LEAN, R.C.

1919 - Studies in the ecology of tropical rain forest with special reference to the forest of south Brazil. J. Ecology, 7: 5-54; 7: 121-174.

MEJSTRIK, V. \& DOMINIK, T.

1969 - The ecological distribution of mycorrhiza of Beech New Phyitologist, 68: 689-700.

PHILlips, J.M. \& HAYMAN, D.S.

1970 - Improved procedures for clearing roots and staining parasitic and Vesicular-Arbuscular mycorrhizal fungi for rapid assessment of infection. Trans. Br. Mycol. Soc., 55: 158-161.

Prance, G.T; RODRIgues, W.A. \& Da SILVA, M.F.

1976 - Inveritário florestal de um hectare de mata de terra firme $\mathrm{km} 30$ da estrada ManausItacoatiara. Acta Amazonica, 6 (1): 9-35.

REDHEAD, J.F.

1968 - Mycorrhizal association in some Nigerian forest trees. Trans. Br. Mycol. Soc., 51 (3): 377387 .

RICHARDS, P.W.

1953 - The tropical rain forest. Cambridge Univ. Press.

RISSER, P.G. \& RICE, E.L

1971 - Phytosociological analysis of Oklahoma uplarid forest species. Ecology, 52: 940-945.
ST. JOHN, T.V.

1980 - Root size, root hairs, and mycorrhizal infection: A re-examination of Baylis's hypothesis with tropical trees. New Phytol. (In press).

ST. JohN, T.V. \& Machado, A.D.

1978 - Efeitos da prcfundidade e do sistema de manejo de un solo de terra firme (latossolo) em infestaçōes por micorrizas. Acta Amazonica, 8: 139-141.

SMALL, E

1972 - Photosynthetic in relation to nitrogen recycling as a adaptation to nutrient deficiency in peat bog plants. Can. J. Bot., 50: 2227-2233.

STARK, N.

1970 - The nutrient content of plants and soils from Brazil and Surinam, Biotropica, 2 (1): 51-60.

WENT, F.W. \& STARK, N.

1968 - Mycorrhiza. Bioscience, 18: 1035-1039.

(Aceito para publicação em 22/01/80) 
APPENDIX - Root depth and mycorrhizal condition of 89 Amazonian tree species

Root depth Mycorrhizal

\begin{tabular}{|c|c|c|}
\hline \multicolumn{3}{|l|}{ Annonaceae } \\
\hline Unonopsis stipitata & $0 \mathrm{~cm} \mathrm{(1)}{ }^{\circ}$ & $H \dagger(1)$ \\
\hline \multicolumn{3}{|l|}{ Apocynaceae } \\
\hline Geissospermum argenteum & $30(2)$ & $L \S(1)$ \\
\hline \multicolumn{3}{|l|}{ Arecaceae } \\
\hline Oenocarpus bacaba & $10(1)$ & $M_{\eta}(2)$ \\
\hline Syagrus $\mathrm{sp}$. & $30(2)$ & $\mathrm{N} E(2)$ \\
\hline \multicolumn{3}{|l|}{ Bombacaceac } \\
\hline Scleronema micranthum & 0 (1) & L (4) \\
\hline \multicolumn{3}{|l|}{ Burseraceae } \\
\hline Protium paraense & $0(1)$ & $\mathrm{H}$ (2) \\
\hline P. pedicellatum & $0(1)$ & $\mathrm{H}$ (2) \\
\hline P. sp. & $0(1)$ & $\mathrm{H} \quad$ (2) \\
\hline Tetragastris $\mathrm{sp}$. & $5(1)$ & L (2) \\
\hline \multicolumn{3}{|l|}{ Caesalpiniaceae } \\
\hline Eperua bijuga & $0(1)$ & H (2) \\
\hline Peltogyne paniculata & $0(1)$ & $\mathrm{H}$ (2) \\
\hline Swartzia reticulata & $80(1)$ & $\mathrm{N}$ (1) \\
\hline s. sp. & $100(3)$ & $\mathrm{N}$ (3) \\
\hline
\end{tabular}

\section{Caryocaraceae .}

Caryocar pallidum

Chrysobalanaceae

Couepia canomensis

Couepia obovata

Licania pallida

Combretaceae

Buchenavia sp.

Connaraceae

Rourea $\mathrm{sp}$.

Dichapetalaceae

Tapura guianensis

Duckeodendraceae

Duckeodendron cestroides

Eleocarpaceae

Sloanea guianensis

Fabaceae

Andira unifoilolata

Dalbergia sp.

Dipteryx odorata

Flacourtiaceae

Laetia procera

Gnetaceae

Gnetum sp.

Hippocrateaceas

Salacia imuressifolia

S. $\mathrm{sp}$.
$O$ (1) H (1)

20 (1) L (1)

$O$ (1) H (1)

$O$ (1) M (1)

$O$ (1) H (1)

30 (1) N (1)

10 (2) L (2)

$O$ (2) M (3)

20 (1)

$O$ (1) M (1)

$O$ (1) H (1)

5 (1) N (1)

o (1) ЕСТО (1)

20 (1) N (1)

20 (1) L (2)
APPENDX (Continuação).

\begin{tabular}{|c|c|c|c|}
\hline \multirow{2}{*}{ Humiriaceae } & \multirow[t]{2}{*}{ depth } & \multicolumn{2}{|c|}{$\begin{array}{l}\text { Mycorrhiza } \\
\text { Condition }\end{array}$} \\
\hline & & & \\
\hline Saccoglottis ceratocarpa & $0(1)$ & L & (1) \\
\hline S. matogrossensis & $20(1)$ & M & (1) \\
\hline \multicolumn{4}{|l|}{ Lauraceae } \\
\hline Aniba Duckei & $O(1)$ & M & (1) \\
\hline Licaria aurea & $0(1)$ & $\mathrm{H}$ & (2) \\
\hline L. sp. & $7(1)$ & M & (1) \\
\hline Nectanda rubra & $0(1)$ & $\mathrm{H}$ & (2) \\
\hline \multicolumn{4}{|l|}{ Lecythidaceae } \\
\hline Corythophora alta & ... & $\mathrm{N}$ & (1) \\
\hline C. rimosa & $150(2)$ & $\mathrm{N}$ & (1) \\
\hline Couratari guianensis & $0(3)$ & $\mathrm{N}$ & (3) \\
\hline Eschweilera amara & $3(2)$ & L & (3) \\
\hline E. odora & $5(3)$ & L & (6) \\
\hline E. polyantha & $7(1)$ & L & (1) \\
\hline E. $s p . ~ 2$ & $0(4)$ & L & (5) \\
\hline E. $\mathrm{sp.} 4$ & $0(2)$ & $\mathrm{N}$ & (2) \\
\hline E. sp. $\check{j}$ & $0(2)$ & $\mathrm{L}$ & (3) \\
\hline E. sp. 6 & $0(2)$ & L & (3) \\
\hline Holopyxidium jaranum & $100(1)$ & & . \\
\hline H. latifolium & $50(2)$ & $\mathrm{N}$ & (3) \\
\hline H. sp. 2 & $50(1)$ & $\mathrm{N}$ & (1) \\
\hline \multicolumn{4}{|l|}{ Leguminosae } \\
\hline sp. & $12(1)$ & M & (1) \\
\hline \multicolumn{4}{|l|}{ Melastomataceae } \\
\hline Mouriria lunatanthera & $0(1)$ & $\mathrm{N}$ & (2) \\
\hline \multicolumn{4}{|l|}{ Meliaceae } \\
\hline Guarea duchei & $50(2)$ & & . \\
\hline Trichilia weddelii & $0(1)$ & M & (1) \\
\hline \multicolumn{4}{|l|}{ Mimosaceas } \\
\hline Pithecolobium racemosum & $0(1)$ & M & (1) \\
\hline \multicolumn{4}{|l|}{ Monimiaceae } \\
\hline Siparuna sp. & $O(1)$ & M & (1) \\
\hline \multicolumn{4}{|l|}{ Moraceae } \\
\hline Brosimum parinariodes & $0(1)$ & $\mathrm{H}$ & (1) \\
\hline B. $s p$. & $0(1)$ & $\mathrm{H}$ & (1) \\
\hline B. utile & $0(5)$ & $\mathrm{H}$ & (5) \\
\hline Ficus sp. & $0(1)$ & $\mathrm{N}$ & (1) \\
\hline Helicostylis $\mathrm{sp}$. & $0(1)$ & $\mathrm{N}$ & (3) \\
\hline H. tomentosa & $0(1)$ & $\mathrm{N}$ & (2) \\
\hline Naucleopsis caloneura & $0(2)$ & $\mathrm{L}$ & (3) \\
\hline sp. & $5(1)$ & $\mathrm{N}$ & (1) \\
\hline \multicolumn{4}{|l|}{ Myrtaceae } \\
\hline Eugenia citrifolia & $7(1)$ & $\mathrm{L}$ & (4) \\
\hline E. egensis & $0(1)$ & $\mathrm{H}$ & (1) \\
\hline \multicolumn{4}{|l|}{ Nyctaginaceae } \\
\hline Neea altissima & $0(2)$ & ECTO & (3) \\
\hline N. sp. & $0(2)$ & ЕСТО & (3) \\
\hline
\end{tabular}


APPENDX (Continuação).

Root depth Mycorrhizal Condition

Ochnaceae

Ouratea discophora

Olaceceae

Heisteria sp.

Minquartia guianensis

Quiinaceae

Quiina pteridophylla

Rhamnaceae

sp.

Rubiaceae

Rudgea (coussarea) $s p$.

sp.

Sapindaceas

sp.

Sapotaceae

Eremoluma sagotiana

Pouteria caimıto

P. guianensis

P. $\mathrm{sp}$.

Prieurella $s p$.

Richardella cladantha

sp.

0 (1) M (2)

0 (2) N (2)

0 (3) N (2)

0 (1) M (1)

0 (2) L (3)

0 (1) M (1)

0 (3) $\mathrm{N}$ (5)

\section{APPENDX (Continuação).}

\begin{tabular}{|c|c|c|c|}
\hline \multirow[b]{2}{*}{ Simarubaceae } & \multirow[t]{2}{*}{ Root depth } & \multicolumn{2}{|c|}{$\begin{array}{l}\text { Mycorrhizal } \\
\text { Condition }\end{array}$} \\
\hline & & & \\
\hline Simaba cuspidata & $150(1)$ & & . \\
\hline \multicolumn{4}{|l|}{ Sterculiaceae } \\
\hline Sterculia sf. Pruriens & $0(1)$ & M & (1) \\
\hline Theobroma $s p$. & $0(1)$ & M & (1) \\
\hline \multicolumn{4}{|l|}{ Tiliaceae } \\
\hline Lueheopsis rosea & $0(1)$ & M & (1) \\
\hline \multicolumn{4}{|l|}{ Violaceae } \\
\hline Rinorea sp. & $0(1)$ & $\mathrm{H}$ & (1) \\
\hline Vochysiaceas & . & & \\
\hline Erisma bicolor & $0(1)$ & $M$ & (1) \\
\hline E. fuscum & $0(1)$ & $M$ & (2) \\
\hline Qualea paraensis & $0(1)$ & M & (2) \\
\hline Q. $\mathrm{sp}$. & $0(1)$ & $M$ & (1) \\
\hline
\end{tabular}

- Numbers in parentheses indicate number of collections examined,

$\dagger \quad \mathrm{H}=$ Heavily infected.

II $M=$ Moderately infected.

$\S L=$ Lightly infected.

$\bar{\varepsilon} \quad N=$ Non-mycorrhizal. 